Nile Green

\title{
JOURNEYMEN, MIDDLEMEN: TRAVEL, TRANSGULTURE, AND TECHNOLOGY IN THE ORIGINS OF MUSLIM PRINTING
}

This essay offers a reinterpretation of the origins of Islamic printing as part of the new global technological and cultural exchanges of the early 19th century. With a special focus on Iranian printers, it reconstructs the interactions of the individual agents of this technological transfer with their European partners. In particular, it traces the emergence of cultural and technological "middlemen" in government employment who traveled to European cities to acquire printing. The "transculturalism" that these middlemen developed was a necessary qualification for success, and here their interaction with missionary organizations and their Arabic typographers proved crucial. They accessed the mass-produced, portable iron handpress, the global proliferation of which in the early 1800s linked pioneer Iranian as well as Indian and Egyptian printers to contemporary developments in England, New Zealand, and America. Islamic printing emerged as less a "late development" than part of the wider globalization of printing that accompanied the Industrial Revolution. 